\title{
PENINGKATAN HASIL BELAJAR MELALUI IMPLEMENTASI MODEL PEMBELAJARAN DISCOVERY LEARNING BERBANTUAN APLIKASI WHATSAPP GROUP PADA MATA KULIAH TEORI SASTRA
}

\author{
LEARNING OUTCOMES IMPROVEMENT THROUGH THE \\ IMPLEMENTATION DISCOVERY LEARNING MODEL USING \\ WHATSAPP GROUP IN LITERATURE THEORY COURSES
}

\author{
Supadi Supadi ${ }^{1}$, Amrizal Amrizal ${ }^{2}$, Fina Hiasa ${ }^{3 *}$ \\ Pendidikan Bahasa Indonesia, Universitas Bengkulu, Indonesia 1, 2, 3 \\ supadi@unib.ac.id ${ }^{1}, \underline{\text { amrizal@unib.ac.id }}^{2}$, finahiasa@unib.ac.id ${ }^{3}$ \\ *penulis korespondensi
}

\begin{tabular}{ll}
\hline Info Artikel & ABSTRAK \\
\hline Sejarah artikel: & Penerapan model discovery learning berbantuan aplikasi WhatsApp group \\
Diterima: & pada mata kuliah Teori Sastra pada penelitian ini bertujuan untuk \\
28 Mei 2021 & meningkatkan hasi belajar mahasiswa semester satu Program Studi \\
Direvisi: & Pendidikan Bahasa Indonesia, FKIP, Universitas Bengkulu. Pengumpulan \\
5 Juli 2021 & data dilakukan dengan teknik tes pada awal dan akhir siklus. Selain itu, \\
Disetujui: & teknik non tes juga digunakan untuk mengetahui respon siswa terhadap \\
17 Juli 2021 & pembelajaran awal dan akhir yang telah berlangsung. Penelitian tindakan \\
& kelas ini dilaksanakan dalam dua siklus. Pada siklus pertama, hasil yang \\
Kata kunci: & diperoleh belum memenuhi target capaian. Target yang ditetapkan tercapai \\
discovery learning, & pada siklus kedua. Hasilnya siswa yang memperoleh nilai A sebanyak 14 \\
Teori Sastra, grup & orang (33\%), nilai B sebanyak 20 orang (50\%), nilai C sebanyak 7 orang \\
WhatsApp & (17\%), dan nilai D sebanyak 0 orang (0\%). Hasil ini menunjukkan \\
& penerapan model discovery learning berbantuan aplikasi WhatsApp group \\
& telah berhasil memenuhi target capaian berupa peningkatan hasil belajar \\
& sebanyak 30\%.
\end{tabular}

\begin{tabular}{ll}
\hline Article Info & ABSTRACT \\
\hline Article history: & The implementation of the discovery learning model assisted by the \\
Received: & WhatsApp group application in the Literary Theory course in this study aims \\
28 May 2021 & to improve the learning outcomes of first semester students of the \\
Revised: & Indonesian Language Education Study Program, FKIP, Bengkulu \\
5 July 2021 & University. Data was collected by using test techniques in the beginning and \\
Accepted: & the end of the cycle. In addition, non-test techniques are also used to \\
17 July 2021 & $\begin{array}{l}\text { determine student responses to the initial and final learning that has taken } \\
\text { place. This classroom action research was carried out in two cycles, in the }\end{array}$ \\
Keyword: & first cycle the results obtained did not reach the achievement targets. The \\
discovery learning, & target's goal was achieved in the second cycle. As a result, 14 students \\
Literary Theory, & (33\%), B grades 20 (50\%), C scores 7 (17\%), and D scores 0 (0\%). These \\
WhatsApp group & $\begin{array}{l}\text { results indicate that the application of the discovery learning model assisted } \\
\text { by the WhatsApp group application has succeeded in the target achievement }\end{array}$ \\
& in the form of 30\% increasing learning outcomes.
\end{tabular}

Copyright $@$ 2021, Stilistika: Jurnal Pendidikan Bahasa dan Sastra DOI: http://dx.doi.org/10.30651/st.v14i2.8325 


\section{PENDAHULUAN}

Pembelajaran Teori Sastra memberikan pemahaman kepada mahasiswa bahwa studi sastra memiliki dasar-dasar yang dapat dipahami untuk memahami karya sastra. Teori sastra sesungguhnya satu dari tiga bidang studi sastra lainnya, yaitu: sejarah sastra, teori sastra, dan kritik sastra. Sastra memiliki tiga konteks sumber dasar pemaknaan diantaranya: pengarang, teks, dan konteks itu sendiri (Mustafa, 2008). Pembelajar dapat memahami makna dari karya sastra dengan memahami: siapakah penulis karya sastra tersebut? Sejatinya teks dan konteks akan menjadi pertimbangan berikutnya untuk mencari makna yang tersembunyi dari karya sastra.

Mata kuliah teori sastra berfokus agar mahasiswa dapat meneliti karya sastra berdasarkan teori-teori sastra yang ada selama ini dengan mempertimbangkan aktivitas pembelajaran yang diberikan dosen kepada mahasiswanya. Aktivitas pembelajaran teori sastra lazim dilaksanakan di ruangan. Namun, semenjak Covid-19 menjadi pandemi global aktivitas pembelajaran menjadi terganggu. World Health Organization (WHO) pada 11 Maret 2020, menyatakan penyakit ini sebagai pandemi global. Universitas Bengkulu sebagai institusi pendidikan telah berupaya mengambil langkah menghentikan penyebaran Covid-19 dengan memberlakukan belajar dari rumah. Akibatnya, dosen dan mahasiswa mengubah pola pembelajaranya dari tatap muka menjadi melalui daring. Permasalahannya, bagaimana dengan model pembelajaran efektif agar mahasiswa tidak mulai bosan dengan pembelajaran selama ini?
Mahasiswa Universitas Bengkulu tumbuh dan berkembang bersama internet saat ini. Teknologi yang dimanfaatkan terarah dalam perkuliahan diharapkan mengoptimalkan sikap tanggung jawab dalam perkuliahan (Basyuni, 2018). Oleh karena itu, dosen akan berupaya menggunakan model pembelajaran yang tepat melalui kelas daring yang dilaksanakan. Salah satu kelas daring dapat digunakan pada aplikasi WhatsApp. Aplikasi ini menyediakan fitur grup yang dapat menjangkau anggota lebih banyak daripada kelas normal pada umumnya. Bukan hanya belajar lebih efektif dan hemat biaya saja, tetapi dosen dan mahasiswa hanya memerlukan kuota internet dan jaringan yang baik untuk dapat menyelesaikan suatu pembelajaran daring.

Pada di WhatsApp group melalui model pembelajaran Discovery learning, dosen dapat menggunakan teknik mengajar model pembelajaran ini dengan mengarahkan mahasiswa untuk menghindari aktivitas pembelajaran yang abstak untuk memulai menghadapi kehidupan nyatanya (Rosarina, Sudin, and Sujana, 2016). Tentu saja, WhatsApp group dan model pembelajaran Discovery learning dapat menjadi solusi dalam pembelajaran daring mata kuliah Teori Sastra pada masa Covid-19 ini. WhatsApp group ialah fasilitas dari WhatsApp untuk membuat suatu grup daring yang terdiri dari anggotaanggota yang memiliki akun WhatsApp masing-masing. WhatsApp ialah pengganti aplikasi SMS namun perbedaan terletak kemampuan aplikasi Whatsapp melampirkan gambar, pesan bersuara, video, dan video call. WhatsApp group dapat dimanfaatkan pihak yang berada di dunia pendidikan 
dalam aktivitas pembelajaranya kepada peserta didik. Aktivitas pembelajaran tidak memerlukan kuliah tatap muka dan pelaksanaan dapat dilaksanakan kapanpun sesuai kesepakatan waktu antara pengajar dan peserta didik. Selain dapat digunakan melalui ponsel, aplikasi ini juga dapat diunduh melalui website resminya di laptop, komputer, dan notebook. Kemudian, tampilan aplikasi akan menyesuaikan dengan tampilan komputer. Jenis Penelitian yang penulis lakukan adalah penelitian tindakan kelas atau disingkat dengan PTK. Hopkins (1993) mengatakan, Penelitian Tindakan Kelas atau disingkat dengan PTK memiliki beberapa karakteristik yaitu sebagai berikut (1) perbaikan proses pembelajaran dari dalam; (2) usaha kolaboratif antara guru dan dosen; dan (3) bersifat fleksibel.

Pernyataan tersebut menunjukan bahwa penelitian tindakan kelas merupakan suatu penelitian tindakan dalam lingkup pendidikan yang dilakukan dosen, dan sekaligus sebagai peneliti dikelasnya atau bersama-sama dengan orang lain (kolaborasi) dengan jalan merancang, melaksanakan, dan merefleksikan tindakan secara kolaboratif dan partisipasif. PTK dipilih dalam pelaksanaan penelitian didasari oleh situasi pembelajaran dari rumah yang dilaksanakan untuk meminimalisisr penyebaran virus covid-19. Pembelajaran dari rumah dalam bentuk daring cenderung merupakan hal baru bagi mahasiswa terutama mahasiswa universitas Bengkulu, maka diperlukan sebuah usaha baik dari pengajar maupun mahasiswa agar tujuan pembelajaran dapat tercapai. Pelaksanaan PTK dalam penelitian ini merupakan wujud inovasi dengan memanfaatkan aplikasi whatsapp yang kebanyakan mahasiswa tahu cara menggunakannya. Tujuannya adalah mempermudah mahasiswa dalam proses pembelajaran secara daring, dengan menerapkan PTK maka pengajar dapat menjadi peka dan tanggap terhadap dinamika pembelajaran daring yang ada pada masa sekarang.

Terdapat beberapa penelitian yang relevan dengan penelitian yang penulis lakuka, yaitu sebagai berikut. Pertama, penelitian Citaningsih (2020) yang berjudul Upaya Meningkatkan Efektifitas Pembelajaran Menulis Teks Deskripsi melalui Metode Discovery learning pada Siswa. Hasil penelitian tersebut adalah 1) Pembelajaran dengan discovery learning memiliki dampak positif dalam meningkatkan prestasi belajar siswa yang ditandai dengan peningkatan ketuntasan belajar siswa dalam setiap siklus, yaitu prasiklus (36\%), siklus I (60\%), siklus II (100\%). 2) Penerapan model pembelajaran discovery learning mempunyai pengaruh positif, yaitu dapat meningkatkan motivasi belajar siswa yang ditunjukan dengan hasil wawancara dengan sebagian siswa, rata-rata jawaban siswa menyatakan bahwa siswa tertarik dan berminat dengan model pembelajaran model discovery learning sehingga mereka menjadi termotivasi untuk belajar. Berdasarkan penelitian tersebut terdapat persamaan dengan penelitian yang penulis lakukan yaitu sama-sama menggunakan model pembelajaran discovery learning. Namun perbedaannya adalah penelitian penulis menggunakan bantuan whatsapp grup dan diterapkan pada mata kuliah teori sastra.

Kedua, adalah penelitian Saragih (2020) yang berjudul Efektivitas Penggunaan WhatsApp Group Selama Pandemi Covid-19 Bagi Pelaku 
Pendidik. Hasil peneltiian ini adalah sebagai berikut $17,65 \%$ dengan kategori sangat baik, 29,4\% dengan kategori baik, 29,4\%\% dengan kategori cukup, $17,65 \%$ dengan kategori kurang dan $6,9 \%$ dengan kategori sangat kurang. Persamaan anatara penelitian tersebut dnegan penelitian yang penulis lakukan adalah sama-sama menggunakan whatsapp grup sebagai media yang membantu kegiatan pembelajaran. Perbedaannya adalah penelitian penulis mengkolaborasikan whatsapp grup dengan model discovery learning. Ketiga, adalah penelitian yang dilakukan oleh Basyuni (2018) dengan judul Penerapan Model Pembelajaran Task-Think-Discussion Berbantuan Group WhatsApp untuk Mengoptimalkan Sikap Tanggung Jawab Mahasiswa Baru. Namun, peneliti belum menemukan penelitian relevan lain yang menggunakan model pembelajaran discovery learning berbantuan WhatsApp group. Masih terbatasnya penelitian tentang peningkatan pembelajaran Teori Sastra dengan model pembelajaran discovery learning melalui WhatsApp group adalah alasan peneliti ingin melakukan penelitian ini. Penerapan penggunaan aplikasi Whatsapp untuk pembelajaran disituasi mahasiswa dilarang berkumpul akibat merebaknya covid19 memang tepat. Harapannya semoga hasil penelitian positif untuk meningkatkan pembelajaran mata kuliah Teori Sastra dan semoga dapat dijadikan referensi untuk diterapkan pada mata kuliah lain terutama untuk mata kuliah sastra.

\section{METODE}

Penelitian yang merupakan Penelitian Tindakan Kelas (Classroom Action Research) ini mengunakan metode deskriptif yang akan menghasilkan deskripsi tentang sejauh mana peningkatan kualitas pembelajaran dengan menggunakan model pembelajaran discovery learning berbantuan aplikasi whatsapp. Penerapan model pembelajaran tersebut dalam matakuliah Teori Sastra memungkinkan mahasiswa memiliki keterlibatan secara aktif dan bermakna dalam kegiatan pembelajaran baik secara individu maupun kelompok sehingga pembelajaran pada matakuliah Teori Sastra menjadi semakin berkualitas.

Peneliti bertidak sebagai bagian dari subyek penelitian yaitu sebagai dosen pengampu mata kuliah Teori Sastra bersama-sama dengan 41 orang mahasiswa semester 1 kelas B yang mengambil mata kuliah tersebut yang sekaligus merupakan sampel dalam penelitian ini. Instrumen penelitian yang digunakan untuk mengumpulkan data penelitian yaitu berupa soal objektif dan juga soal essai yang dapat diakses pada grup whatsapp. Tujuan dari tes ini adalah untuk mengukur tingkat penguasaan materi siswa. Statistik deskriptif adalah teknik analisis data yang digunakan dalam penelitian yakni berbentuk persentase yang disajikan dalam bentuk tabel atau grafik yang kategori pada data akan disesuaikan dengan persentase yang tersedia pada hasil penelitian. Berikut adalah rumus yang akan digunakan dalam pengolahan data.

$$
\mathrm{X}=\frac{€ \mathrm{X}}{€ \mathrm{Xmaks}} \mathrm{x} 100 \%
$$

Keterangan

$\mathrm{X}=$ nilai yang dicari dalam persen

$€ X=$ Jumlah nilai mahasiswa

$€$ Xmaks $=$ Jumlah skor total 
Tabel 1. Kategori Penilaian

\begin{tabular}{|l|l|l|}
\hline No & \multicolumn{1}{|c|}{ Persentasi } & \multicolumn{1}{c|}{ Katagori } \\
\hline 1 & $80 \%-100 \%$ & Sangat baik (A) \\
\hline 2 & $70 \%-79 \%$ & Baik (B) \\
\hline 3 & $60 \%-69 \%$ & Cukup baik (C) \\
\hline 4 & $45 \%-59 \%$ & Kurang baik (D) \\
\hline \multicolumn{2}{|r}{ (Nurgiyantoro, 2010) }
\end{tabular}

\section{HASIL DAN PEMBAHASAN}

Hasil akhir dari penelitian yang telah dilakukan pada 41 orang mahasiswa PBI dengan tujuan untuk meningkatkan kualitas pembelajaran pada matakuliah Teori Sastra dengan mengimplementasikan model pembelajaran discovery learning Berbantuan Aplikasi WhatsApp Group yang terdiri dari 2 siklus adalah sebagai berikut.

Tabel 2. Hasil Belajar Siklus 1 dan 2

\begin{tabular}{|c|c|c|c|c|c|c|c|}
\hline $\begin{array}{c}\text { RENTANG } \\
\text { NILAI }\end{array}$ & HURUF & DESKRIPSI & \multicolumn{2}{|c|}{$\begin{array}{l}\text { PEROLEH } \\
\text { AN NILAI } \\
\text { SIKLUS } 1\end{array}$} & \multicolumn{2}{|c|}{$\begin{array}{c}\text { PEROLEHAN } \\
\text { NILAI } \\
\text { SIKLUS II }\end{array}$} & $\begin{array}{c}\text { TARGET } \\
\text { CAPAIAN/KE } \\
\text { TUNTASAN } \\
\text { REI IAR }\end{array}$ \\
\hline $80-100$ & A & Sangat baik & 11 & $28 \%$ & 14 & $33 \%$ & $30 \%$ \\
\hline $65-79$ & B & Baik & 19 & $48 \%$ & 20 & $50 \%$ & $50 \%$ \\
\hline $55-64$ & $\mathrm{C}$ & Cukup baik & 11 & $24 \%$ & 7 & $17 \%$ & $20 \%$ \\
\hline $0-54$ & $\mathrm{D}$ & Kurang baik & 0 & $0 \%$ & 0 & $0 \%$ & $0 \%$ \\
\hline \multicolumn{3}{|c|}{ Jumlah } & 41 & $\begin{array}{c}100 \\
\%\end{array}$ & 41 & $100 \%$ & $100 \%$ \\
\hline
\end{tabular}

Selanjutnya akan dijelaskan detil kegiatan pembelajaran yang dibagi menjadi dua siklus yang panduannya terletak pada langkah-langkah operasional dalam pengajaran discovery learning berikut:

a. Pengajar menentukan tujuan pembelajaran.

b. Pengajar menganalisis karakteristik peserta didik.

c. Pengajar menetukan materi pelajaran.

d. Pengajar mengembangkan bahwan ajar yang digunakan untuk peserta didik.

e. Pengajar menentukan topik belajar dari sederhana ke kompleks.

f. Peserta didik memahami materi dan tugas yang diberikan oleh pengajar.

g. Peserta didik menyusun dugaan sementara terhadap materi dan tugas yang diberikan pengajar. h. Setelah menyusun dugaan, maka pengajar mempersilakan peserta didik untuk memulai kerjanya.

i. Setelah peserta didik selesai dengan pekerjaannya, pengajar memberikan tugas terbaru sebagai bahan latihan selanjutnya.

j. Pengajar melaksanakan penilaian sebagai evaluasi bagi pembelajaran peserta didik.

\section{Siklus 1}

Pada siklus 1, perencanaan yang dilakukan oleh pengajar adalah dengan mempersiapkan perangkat pembelajaran untuk proses belajar mahasiswa Teori Sastra kelas 1A, yaitu sebagai berikut: Rancangan Pembelajaran Semester (RPS) disusun oleh dosen, Lembar kerja kelompok 1 , 2, dan 3 disiapkan dosen, Soal kuis 1, 2, dan 3 yaitu 5 soal esai tiap kuis 
disiapkan dosen, Soal Pra Mid semester yaitu 15 pilihan ganda dan 5 soal esai disiapkan dosen, Dosen menyiapkan whatsapp grup sebagai sumber menjawab soal-soal kuis dan pra mid semester.

Selanjutnya pada tahap pelaksanaan, pengajar menyampaikan tujuan pembelajaran kepada mahasiswa di whatsApp grup yang telah disediakan. Pada ruang whatsapp tersebut mahasiswa dan dosen saling menyapa dan memperkenalkan diri. Dari percakapan singkat tersebut maka akan mulai tampak peserta didik yang pasif maupun yang aktif. Dengan melihat situasi ruang kelas pada whatsapp tersebut maka dosen menyusun strategi agar materi yang akan dipelajari dapat dipahami oleh mahasiswa. Pada siklus 1 ini dosen menggunakan model pembelajaran konvensional dimana dosen menyampaikan materi melalui whatsapp grup dengan cara membagikan materi dalam bentuk PPT agar dapat dibaca dan dipahami oleh mahasiswa.

Penyampaian materi ini serupa dengan penyampaian materi yang biasanya terjadi di ruang kelas, yang menjadi pembedanya ruang yang digunakan kali ini adalah ruang virtual dengan memanfaatkan aplikasi whatsapp. Setelah mahasiswa diberikan waktu khusus untuk membaca materi dalam bentuk PPT yang telah dibagikan oleh dosen sebelumnya, selanjutnya dosen meminta mahasiswa untuk bertanya setelah melakukan aktivitas membaca materi pembelajaran. Butuh beberapa waktu akhirnya ada mahasiswa yang bertanya pada ruang whatsapp tersebut dan akhirnya disusul dengan pertanyaan dari mahasiswa lain. Pada tahap ini dosen berusaha menjelaskan apa yang ditanyakan oleh mahasiswa sampai mahasiswa paham. Asumsi awal setelah pembelajaran berakhir adalah mahasiswa mengerti atas materi yang disampaikan melalui PPT dan penjelasan yang dipaparkan oleh pengajar. Selanjutnya dosen menyiapkan soal kuis I dan II yang tiap kuis terdiri dari 5 soal. Pelaksanaan kuis ini dilakukan pada tiap akhir pertemuan untuk melihat sejauh mana pemahaman mahsiswa atas materi yang diberikan oleh dosen. Adapun total dari hasil nilai kuis yang diperoleh mahasiswa pada siklus 1 ialah sebagai berikut.

Tabel 3. Hasil Evaluasi pada Siklus 1

\begin{tabular}{|c|c|c|c|c|c|}
\hline $\begin{array}{c}\text { Rentang } \\
\text { Nilai }\end{array}$ & Huruf & Deskripsi & \multicolumn{2}{c|}{$\begin{array}{c}\text { PEROLEHAN } \\
\text { NILAI } \\
\text { SIKLUS 1 }\end{array}$} & $\begin{array}{c}\text { Target } \\
\text { capaian/ketuntasan } \\
\text { belajar }\end{array}$ \\
\hline $80-100$ & A & Sangat baik & 11 & $28 \%$ & $30 \%$ \\
\hline $65-79$ & B & Baik & 19 & $48 \%$ & $50 \%$ \\
\hline $55-64$ & C & Cukup baik & 11 & $24 \%$ & $20 \%$ \\
\hline $0-54$ & D & Kurang baik & 0 & $0 \%$ & $0 \%$ \\
\hline \multicolumn{3}{|c|}{ Jumlah } & 41 & $100 \%$ & $100 \%$ \\
\hline
\end{tabular}

Berdasarkan hasil tabel di atas, tampak bahwa hasil kuis pada siklus 1 adalah sebagai berikut. Mahasiswa yang memperoleh nilai A sejumlah 11 orang, nilai B sejumlah 19 orang, nilai C sejumlah 11 orang, dan nilai D 
sejumlah 0 orang. Berdasarkan hasil tersebut dapat disimpulkan bahwa asumsi awal bahwa mahasiswa telah mengerti materi yang disampaikan dengan melihat kondisi sedikitnya mahasiswa yang bertanya ketika diminta dapat dikatakan tidak valid. Hasil menunjukkan hanya mahasiswa tertentu yang menikmati pembelajaran mandiri dan akhirnya memperoleh nilai maksimal pada kuis I dan II. Namun masih cukup banyak mahasiswa yang tidak dapat menikmati pembelajaran satu arah yang diadakan pada ruang virtual whatsapp grup akibat dari pandemi covid-19. Hal ini tampak dari hasil yang didapatkan mahasiswa pada kuis I dan II yang kurang maksimal.

Berdasarkan situasi tersebut maka dibutuhkan sebuah model pembelajaran yang cocok diterapkan pada masa pandemi dimana keseluruhan pembelajaran bersifat daring. Peneliti menerapkan model pembelajaran discovery learning berbantuan whatsapp grup yang aplikasi ini sudah familiar bagi mahasiswa. Selain ekonomis aplikasi ini juga efektif seperti penggunaan email. Pada model pembelajaran discovery learning mahasiswa akan memiliki keterlibatan penuh dalam pembelajaran. Arah pembelajaran tidak lagi hanya satu sebab mahasiswa dapat berpartisipasi aktif di dalam kelompok. Maka dari itu melihat hasil yang di dapat dari siklus 1 maka peneliti memutuskan hasil refleksi adalah dengan melanjutkan ke siklus 2 dengan melakukan penerapan model pembelajaran discovery learning yang harapannya nilai target belajar mahasiswa dapat tercapai.

\section{Siklus 2}

Pada siklus ke-2 ini, dosen telah menyiapkan hal-hal sebagai berikut pada tahap perencanaan, yaitu lembar kerja kelompok dan soal kuis berbentuk pilihan ganda dan esai. Dosen mengkondisikan kelas virtual WhatsApp-nya dimana nantinya mahasiswa akan melakukan presentasi secara virtual pada ruang whatsapp grup yang disediakan. Sebelumnya dosen juga menentukan pokok-pokok materi yang harus ada pada penyampaian presentasi yang dilakukan oleh mahasiswa agar target dari tujuan pembelajaran dapat tercapai seperti harus terdapat latar belakang, tokoh pelopor, paparan teori, dan contoh dalam menganalisis karya sastra dengan menggunakan teori tersebut. Dosen juga memilih cara kerja kelompok karena situasi pandemic covid 19 yang menyebabkan antarmahasiswa yang masih berada pada semester pertama cenderung belum mengenal satu sama lain. Dengan adanya sistem kerja kelompok mahasiswa akan berusaha menghubungi, mengenal dan akhirnya bekerja sama dengan teman yang belum pernah ditemuinya secara langsung. Sistem kerja kelompok ini juga memudahkan mahasiswa dalam memahami materi tertentu dimana materi tersebut ditentukan secara acak yang nantinya harus dipresentasikan oleh tiap kelompok. Kelompok yang telah dibentuk akan menjelaskan topik sebagai berikut: Teori Pendekatan Strukturalisme, Strukturalisme Genetik, dan Strukturalisme Levisstauss.

Pada tahap pelaksanaan ini mahasiswa menelusuri sendiri ilmu yang akan mereka presentasikan dengan cara mencari buku ataupun jurnal-jurnal pendukung untuk menjadi materi yang akan tiap kelompok presentasikan. Kegiatan ini menuntut mahaiswa untuk berperan aktif dalam 
pembelajaran dan dengan mahasiswa berperan sebagai narasumber maka secara tidak langsung mahasiswa wajib menguasai materi yang menjadi bahan presentasinya. Semua kegiatan presentasi tersebut dilakukan pada ruang whatsap grup, selain itu kegiatan tanya jawab yang dilakukan ditiap akhir penyampaian materi juga diwadahi oleh ruang whatsapp grup.

Kegiatan pembelajaran yang biasanya terjadi di ruang kelas dapat dipindahkan ke dalam ruang digital yang mungkin dapat dikatakan sederhana karena hanya menggunakan aplikasi whatsapp grup. Aplikasi yang sudangat familiar bagi kebanyakan orang ini memudahkan mahasiswa dalam menghadapi situasi belajar yang biasanya terjadi di ruang kelas berganti menjadi ke ruang digital dengan system daring. Setelah semua kelompok selesai mempresentasikan dosen memberikan tes berupa pengerjaan soal berbentuk tes dan pilihan ganda yang tujuannya adalah untuk mengetahui sejauh mana pemahaman mahasiwa atas materi yang telah dipelajari. Adapun hasil nilai dari mahasiswa pada siklus 2 ialah sebagai berikut.

Tabel 4. Hasil Evaluasi pada Siklus 2

\begin{tabular}{|c|c|c|c|c|c|}
\hline $\begin{array}{c}\text { Rentang } \\
\text { Nilai }\end{array}$ & Huruf & Deskripsi & \multicolumn{2}{|c|}{$\begin{array}{c}\text { PEROLEHAN } \\
\text { NILAI } \\
\text { SIKLUS II }\end{array}$} & $\begin{array}{c}\text { Target } \\
\text { capaian/ketuntasan } \\
\text { belajar }\end{array}$ \\
\hline $80-100$ & A & Sangat baik & 14 & $33 \%$ & $30 \%$ \\
\hline $65-79$ & B & baik & 20 & $50 \%$ & $50 \%$ \\
\hline $55-64$ & C & Cukup baik & 7 & $17 \%$ & $20 \%$ \\
\hline $0-54$ & D & Kurang baik & 0 & $0 \%$ & $0 \%$ \\
\hline \multicolumn{3}{|c|}{ Jumlah } & 41 & $100 \%$ & $100 \%$ \\
\hline
\end{tabular}

Dari tabel di atas dapat dilihat bahwa perolehan nilai mahasiswa pada siklus II menunjukan hasil belajar mencapai target capaian yaitu sebanyak 14 mahasiswa (33\%) memperoleh A. Sebanyak 20 mahasiswa $(50 \%)$ memperoleh nilai B. Lalu sebanyak 7 mahasiswa (17\%) memperoleh nilai C. Artinya hasil belajar mahasiswa sesuai dengan target yang telah ditetapkan sebelumnya. Penelitian TIndakan Kelas untuk meningkatkan hasil belajar dengan model pembelajaran discovery learning berbantuan aplikasi WhatsApp group ini adalah pembaharuan dari penelitian sebelumnya, dimana pada penelitian ini model discovery learning tidak diterapkan pada penelitian sebelumnya.
Melalui model ini peserta didik secara partisipatif hadir secara individu maupun berkelompok dalam mengeksplorasi pengetahuan yang menjadi pokok pembelajaran. Kesimpulannya implementasi model pembelajaran discovery learning berbantuan aplikasi WhatsApp group dapat meningkatkan hasil belajar pada mata kuliah Teori Sastra.

\section{PENUTUP}

Hasil penelitian menunjukkan model pembelajaran discovery learning berbantuan WhatsApp group pada mata kuliah Teori Sastra dapat meningkatkan hasil belajar mahasiswa. Ketuntasan belajar diperoleh secara keseluruhan dari siklus 2. Adanya peningkatan hasil 
belajar ini membuktikan bahwa model pembelajaran discovery learning berbantuan WhatsApp group dapat menjadi salah satu model pembelajaran secara daring. Diharapkan dosen dapat menerapkan model pembelajaran discovery learning berbantuan WhatsApp group untuk mata kuliah Teori Sastra selanjutnya. Diharapkan dosen dapat memilih teknik mengajar lainnya sehingga menarik bagi mahasiswa dalam mencari ilmu selama perkuliahan ini.

\section{DAFTAR PUSTAKA}

Basyuni, Bistari. (2018). "Penerapan Model Pembelajaran Task-ThinkDiscussion Berbantuan Group Whatsapp Untuk Mengoptimalkan Sikap Tanggung Jawab Mahasiswa Baru." Pembelajaran Prospektif 3.

\section{Citaningsih (2020). Upaya Meningkatkan Efektifitas Pembelajaran Menulis Teks Deskripsi Melalui Metode Discovery Learning Pada Siswa. Journal for Lesson and Learning Studies Vol. 3 No.1, April 2020, 66-79}

Emzir, And Saifur Rohman. (2015). Teori Dan Pengajaran Sastra. Depok: Raja Grafindo Persada.
Hopkins, David. (1993). A Teacher's Guide to Classroom Research. Second Edition. Philadelphia: Open University Press.

Margaretha, Eva dan Rahma Yunita Ansi. (2020). "Efektivitas Penggunaan Whatsapp Group Selama Pandemi Covid-19 Bagi Pelaku Pendidik". Prosiding Seminar Nasional Multidisiplin Ilmu Universitas Asahan ke-4 Tahun 2020, hlm 207-2012

Mustafa, Bachrudin. (2008). Teori Dan Praktik Sastra. Jakarta: Cahaya Insan Sejahtera.

Nurgiyantoro, B. (2010). Penilaian Pembelajaran Bahasa. Yogyakarta: BPFE

Putra, Nusa. (2011). Research \& Development. Jakarta: Raja Grafindo Persada.

Rosarina, Gina, Ali Sudin, And Atep Sujana. (2016). "Penerapan Model Discovery Learning Untuk Meningkatkan Hasil Belajar Siswa Pada Materi Perubahan Wujud Benda" 1 (1): 371-80.

Widokyo. (2009). Evaluasi Program Pembelajaran. Yogyakarta: Pustaka Pelajar. 